\title{
Kemampuan Guru Biologi dalam Pengimplementasian Kurikulum 2013 Ditinjau dari Kompetensi Pedagogik
}

\author{
Binar Azwar ${ }^{1}$, Anas Harfian ${ }^{2}$ \\ ${ }^{1,2}$ FKIP Universitas Muhammadiyah Palembang, Indonesia
}

Pengiriman: 25 September 2017; Diterima: 2 Maret 2018; Publikasi: Maret 2018

\begin{abstract}
This research aims to determine the level of biological teachers ' ability in implementing curriculum 2013 in schools is reviewed from the pedagogic competence at SMA Negeri Sleman Regency. The study used a survey method with samples of five teachers from a population of seven teachers. Sampling technique with purposive sampling. The instruments used are polls, interview guidelines, observation guidelines, and documentation. Data analysis with quantitative and qualitative descriptive analytical techniques. The results of his research are the ability of biology teachers in implementing curriculum 2013 is reviewed from the pedagogic competence in SMA Negeri Sleman, which is one teacher with a very capable category, three teachers with the category can, And one teacher with the category is quite capable.
\end{abstract}

Keywords: Pedagogic competence, biological teacher, curriculum 2013

\begin{abstract}
ABSTRAK: Penelitian ini bertujuan untuk mengetahui tingkat kemampuan guru biologi dalam mengimplementasikan Kurikulum 2013 di sekolah ditinjau dari kompetensi pedagogik di SMA Negeri Kabupaten Sleman. Penelitian ini menggunakan metode survei dengan sampel lima orang guru dari populasi sebanyak tujuh orang guru. Teknik pengambilan sampelnya dengan purposive sampling. Instrumen yang digunakan adalah angket, pedoman wawancara, pedoman observasi, dan dokumentasi. Analisis data dengan teknik analisis deskriptif kuantitatif dan kualitatif. Hasil penelitiannya adalah tingkat kemampuan guru biologi dalam mengimplementasikan Kurikulum 2013 ditinjau dari kompetensi pedagogik di SMA Negeri Kabupaten Sleman yaitu satu orang guru dengan kategori sangat mampu, tiga orang guru dengan kategori mampu, serta satu orang guru dengan kategori cukup mampu.
\end{abstract}

Kata Kunci: kompetensi pedagogik, guru biologi, kurikulum 2013

*Penulis Korespondensi:

Alamat surel: binar.azwar@gmail.com 


\section{PENDAHULUAN}

Pemerintah melalui Kementerian Pendidikan dan Kebudayaan telah menetapkan implementasi Kurikulum 2013 secara terbatas dan bertahap mulai tahun ajaran 2013/2014 pada semua jenjang pendidikan di sekolah sasaran. Mulyasa (2010:178) menyatakan implementasi merupakan penerapan ide, konsep, kebijakan, atau inovasi dalam suatu tindakan praktis, sehingga memberikan dampak, baik berupa perubahan pengetahuan, keterampilan, nilai, dan sikap. Ghufron (2008:7) memahami implementasi kurikulum sebagai suatu kegiatan yang bertujuan untuk mewujudkan kurikulum (dalam arti rencana tertulis) ke dalam bentuk kegiatan nyata di kelas, yaitu melakukan proses transmisi dan transformasi segenap pengalaman belajar kepada peserta didik.

Berdasarkan beberapa pengertian tersebut, implementasi kurikulum dapat dipahami sebagai proses penerjemahan dan penerapan seperangkat rencana dan pengaturan mengenai tujuan, isi, dan bahan pelajaran serta cara yang digunakan sebagai penyelenggaraan kegiatan pembelajaran untuk mencapai tujuan pendidikan tertentu. Implementasi kurikulum merupakan bagian penting dalam menentukan sebuah proses perubahan dalam pembelajaran. Keberhasilan proses pelaksanaan dipengaruhi kemampuan guru dan kepala sekolah dalam mendesain proses pembelajaran. Implementasi juga dapat dipahami sebagai proses penerapan ide, program atau seperangkat aktifitas dengan harapan orang lain dapat menerima dan melakukan perubahan.

Penerapan Kurikulum 2013, memerlukan penyesuaian guru dalam mengemas pembelajaran sesuai dengan yang tertuang dalam Kurikulum 2013. Pelaksanaan pembelajaran biologi dalam Kurikulum 2013 memerlukan kemampuan yang berkaitan dengan konten materi biologi maupun cara membelajarkan biologi. Kondisi ini tentu saja berkaitan dengan kompetensi yang dimiliki guru. McAshan (Mulyasa, 2005:38) mengemukakan bahwa kompetensi "...is knowledge, skills, and abilities or capabilities that a person achieves, which become part of his or her being to the exent he or she can satisfactorily perform particular cognitive, affective, and psycomotor behaviors". Kompetensi diartikan sebagai pengetahuan, keterampilan, dan kemampuan yang dikuasai oleh seseorang yang telah menjadi bagian dari dirinya, sehingga ia dapat melakukan perilakuperilaku kognitif, afektif dan psikomotor dengan sebaik-baiknya. Kompetensi juga diartikan sebagai suatu kemampuan yang dimiliki oleh seseorang untuk melakukan tindakan profesional secara efektif dan efisien. Dalam hal ini kompetensi dihubungkan dengan skills yang berhasil dikuasai oleh seseorang sehingga dia dapat melakukan suatu tugas atau pekerjaan dengan baik dan berhasilguna.

Implementasi kurikulum sangat ditentukan oleh kompetensi guru. Kompetensi yang dimaksud yaitu kompetensi pedagogik, kompetensi profesional, kompetensi kepribadian, dan kompetensi sosial. Seperti yang diungkapkan oleh Setyarahajoe dan Irtanto (2013) yaitu "The task of teachers as the morality guard should be fully awarded by teachers because the three demands of four competences which should be had by teachers will have goal on the demand of humanity values and morality values that are pedagogic competence, professional competence, personality competence, and social competence". Secara tersirat, Setyarahajoe mengungkapkan bahwa guru harus memiliki 4 kompetensi utama yaitu kompetensi pedagogik, kompetensi profesional, kompetensi kepribadian, dan kompetensi sosial.

Berdasarkan data tentang hasil Uji Kompetensi Guru (UKG), Mohamad Nuh mengatakan bahwa kualitas guru di Indonesia masih rendah dan hanya mencapai skor 44,5 . Nilai ini tidak jauh berbeda dengan rata-rata skor Uji Kompetensi Awal (UKA), yaitu 42. Berdasarkan data tersebut, menunjukkan 
bahwa guru kurang berkompeten dalam pengajaran. Menyadari hal tersebut, pemerintah telah melakukan upaya untuk mengembangkan kompetensi guru dengan melakukan workshop dan pelatihan, namun tidak semua pesan bisa tersampaikan.

Berdasarkan hasil wawancara terhadap beberapa guru biologi kelas X dan XI SMA Negeri di Kabupaten Sleman yang telah menerapkan Kurikulum 2013, diperoleh informasi bahwa tidak semua guru mendapatkan pelatihan tentang Kurikulum 2013, sehingga belum tentu guru yang sekolahnya ditunjuk oleh pemerintah untuk mengimplementasikan Kurikulum 2013 mampu dalam mengimplementasikan Kurikulum 2013, guru masih kebingungan dalam mengembangkan perangkat pembelajarannya, belum tersedianya buku ajar sebagai buku pegangan guru ataupun buku pegangan siswa, sulitnya menyesuaikan waktu yang tersedia dengan materi yang harus disampaikan, guru merasa kesulitan mengingat secara mendetail aktivitas masing-masing siswa dalam penilain sikap dan terkesan kurang objektif. Beberapa kendala itulah yang menjadi dasar pemikiran untuk melihat secara dekat tentang kemampuan guru biologi dalam pengimplementasian Kurikulum 2013 ditinjau dari kompetensi pedagogik di SMA Negeri Kabupaten Sleman.

Adapun rumusan masalah dari penelitian ini adalah berapa persen tingkat kemampuan guru biologi dalam mengimplementasikan Kurikulum 2013 ditinjau dari kompetensi pedagogik di SMA Negeri Kabupaten Sleman? Berdasarkan perumusan masalah, tujuan penelitian yang akan dicapai dalam penelitian ini adalah mengetahui persentase tingkat kemampuan guru biologi dalam mengimplementasikan Kurikulum 2013 di sekolah ditinjau dari kompetensi pedagogik di SMA Negeri Kabupaten Sleman.

\section{METODE PENELITIAN}

\section{HASIL DAN PEMBAHASAN}

Hasil analisis deskriptif dengan menggunakan program Excel 2013 menunjukkan bahwa rerata skor keseluruhan untuk semua komponen penelitian ini yaitu 278,8 dengan mean sebesar 55,76. Hasil analisis data kemampuan total dapat dilihat dalam tabel kemampuan guru biologi SMA Negeri Kabupaten Sleman dalam mengimplementasikan Kurikulum 2013, seperti yang terangkum dalam Tabel 1 .

Tabel 1. Kemampuan Guru Biologi

Mengimplementasikan Kurikulum 2013

\begin{tabular}{cccc}
\hline No & Nama Sekoah & $\begin{array}{c}\text { Jumlah } \\
\text { Skor }\end{array}$ & Kriteria \\
\hline 1 & $\begin{array}{c}\text { SMAN 1 } \\
\text { Prambanan }\end{array}$ & 314 & $\begin{array}{c}\text { Sangat } \\
\text { Mampu }\end{array}$ \\
\hline 2 & SMAN 2 Ngaglik & 263 & Mampu \\
\hline 3 & SMAN 1 Pakem & 265 & Mampu \\
\hline 4 & SMAN 1 Seyegan & 259 & Mampu \\
\hline 5 & SMAN 1 Godean & 293 & Mampu \\
\hline & Total Skor & 1394 & \\
\hline
\end{tabular}

Rangkuman pada Tabel 1 memberikan gambaran bahwa satu orang guru biologi kelas XI di SMA Negeri Kabupaten Sleman yang mengimplementasikan Kurikulum 2013 masuk dalam kategori sangat mampu, sedangkan 4 orang masuk dalam kategori mampu untuk mengimplementasikan Kurikulum 2013.

Implementasi Kurikulum 2013 menurut Mulyasa (2014:99) merupakan aktualisasi kurikulum dalam pembelajaran dan pembentukan kompetensi serta karakter peserta didik. Hal tersebut menuntut kemampuan guru dalam menciptakan dan menumbuhkan berbagai kegiatan sesuai dengan rencana yang telah diprogramkan. Kemampuan guru tersebut ada pada kompetensi yang harus dimilikinya yaitu kompetensi pedagogik.

Kompetensi pedagogik yang diteliti meliputi (a) menguasai karakteristik peserta didik dari aspek fisik, moral, spiritual, sosial, kultural, 
emosional, dan intelektual; (b) menguasai teori belajar dan prinsip-prinsip pembelajaran yang mendidik; (c) mengembangkan kurikulum yang terkait dengan mata pelajaran yang diampu; (d) menyelenggarakan pembelajaran yang mendidik; (e) memanfaatkan teknologi informasi dan komunikasi untuk kepentingan pembelajaran; (f) memfasilitasi pengembangan potensi peserta didik untuk mengaktualisasikan berbagai potensi yang dimiliki; (g) berkomunikasi secara efektif, empatik, dan santun dengan peserta didik; (h) menyelenggarakan penilaian dan evaluasi proses dan hasil belajar; (i) memanfaatkan hasil penilaian dan evaluasi untuk kepentingan pembelajaran; dan (j) melakukan tindakan reflektif untuk meningkatkan kualitas pembelajaran. Kompetensi pedagogik guru tersebut diungkap melalui angket, wawancara, dan studi dokumentasi berupa RPP.

Berdasarkan hasil analisis data, kemampuan guru mengimplementasikan Kurikulum 2013 ditinjau dari kompetensi pedagogik di SMA Negeri Kabupaten Sleman dapat dilihat pada Gambar 1

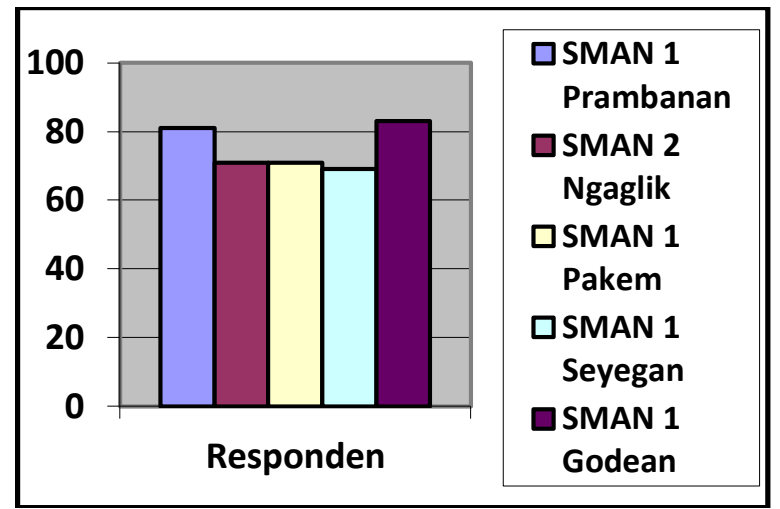

Gambar 1. Diagram Persentase Tingkat

Kompetensi Pedagogik Guru Biologi SMA Adapun hasil dari masing-masing sekolah akan dijabarkan sebagai berikut.

\section{a. SMAN 1 Prambanan}

Berdasarkan hasil analisis angket dari guru tentang kemampuan guru mengimplementasikan Kurikulum 2013 ditinjau dari kompetensi pedagogik guru biologi, total skor yang diperoleh adalah 100 $(81 \%)$ dan masuk dalam kategori mampu. Skor ini merupakan hasil isian angket yang diberikan kepada guru biologi yang terdiri atas 34 butir soal untuk menilai 10 indikator kompetensi pedagogik guru dalam mengimplementasikan Kurikulum 2013.

Dari 10 indikator tentang kompetensi pedagogik guru, indikator keempat yaitu kemampuan guru dalam menyelenggarakan pembelajaran yang mendidik mendapatkan skor terendah yaitu 12 dari skor maksimal 20. Skor ini diperoleh karena guru jarang menggunakan model pembelajaran seperti yang diharapkan oleh Kurikulum 2013. Berdasarkan wawancara dengan guru diketahui bahwa dalam satu semester, guru menggunakan model pembelajaran yang sesuai dengan Kurikulum 2013 sebanyak 2 kali. Hal ini disebabkan karena menurut pendapat guru, tidak semua materi biologi khususnya pada kelas XI dapat menggunakan model tersebut. Selain itu, peserta didik juga merasa kurang mampu jika harus menggunakan model pembelajaran yang seperti diharapkan Kurikulum 2013.

\section{b. SMAN 2 Ngaglik}

Berdasarkan hasil analisis angket dari guru tentang kemampuan guru mengimplementasikan Kurikulum 2013 ditinjau dari kompetensi pedagogik guru biologi, total skor yang diperoleh adalah 88 (71\%), sehingga masuk dalam kategori mampu. Skor ini merupakan hasil isian angket yang diberikan kepada guru biologi yang terdiri atas 34 butir soal untuk menilai 10 indikator kompetensi pedagogik guru dalam mengimplementasikan Kurikulum 2013.

Seperti halnya guru SMAN 1 Prambanan, dari 10 indikator tentang kompetensi pedagogik guru, indikator keempat yaitu kemampuan guru dalam menyelenggarakan pembelajaran yang mendidik mendapatkan skor terendah yaitu 9 dari skor maksimal 20. Berdasarkan 
angket yang diisi guru, dalam satu semester guru hanya sekali menggunakan model pembelajaran Problem Based Learning, Discovery Learning, dan Cooperative Learning, sedangkan model pembelajaran Inquiry hanya sebanyak dua kali dalam satu semester. Hal ini tidak seperti yang diharapkan dalam Kurikulum 2013, yaitu guru mampu menggunakan pendekatan saintifik dalam pembelajaran di kelas. Berdasarkan wawancara terhadap guru, guru merasa sangat kesulitan dalam menerapkan pendekatan saintifik karena peserta didik kelas XI cenderung pasif ketika guru menggunakan pendekatan ini. Peserta didik sangat membutuhkan peran guru dalam pembelajaran di kelas, selain itu meskipun pendekatan saintifik tidak asing pada mata pelajaran biologi, ternyata peserta didik juga masih perlu beradaptasi terhadap pendekatan ini karena di kelas sebelumya guru masih menggunakan pembelajaran konvensional dalam mengajar di kelas.

\section{c. SMAN 1 Pakem}

Berdasarkan hasil analisis angket dari guru tentang kemampuan guru mengimplementasikan Kurikulum 2013 ditinjau dari kompetensi pedagogik guru biologi, total skor yang diperoleh adalah 88 (71\%), sehingga masuk dalam kategori mampu. Skor ini merupakan hasil isian angket yang diberikan kepada guru biologi yang terdiri atas 34 butir soal untuk menilai 10 indikator kompetensi pedagogik guru dalam mengimplementasikan Kurikulum 2013.

Untuk guru SMA Negeri 1 Pakem, dari 10 indikator tentang kompetensi pedagogik guru, indikator keempat yaitu kemampuan guru dalam menyelenggarakan pembelajaran yang mendidik serta indikator keenam tentang kemampuan guru dalam memfasilitasi pengembangan potensi peserta didik untuk mengaktualisasikan berbagai potensi yang dimiliki mendapatkan skor terendah yaitu 12 dari skor maksimal 20 untuk indikator keempat dan skor 22 dari skor maksimal 30 untuk indikator keenam. Skor ini diperoleh berdasarkan angket yang diisi oleh guru . Pada indikator keempat, diketahui bahwa guru pernah 2 kali dalam menggunakan model pembelajaran Problem Based Learning, Inquiry, Discovery Learning, dan Cooperative Learning dalam satu semester. Jumlah ini termasuk kategori jarang dalam menggunakan model pembelajaran seperti yang diharapkan oleh Kurikulum 2013. Berdasarkan wawancara terhadap peserta didik diketahui bahwa guru jarang menggunakan model pembelajaran ini karena guru cenderung fokus terhadap konsep materi yang diajarkan oleh guru. Dalam hal ini, guru lebih banyak ceramah dan memberikan LKS untuk dikerjakan peserta didik. guru memancing pengetahuan peserta didik dengan cara memberikan pertanyaan terkait dengan materi yang diajarkan, kemudian dari jawaban peserta didik guru memberikan penjelasan apabila kurang tepat. Selain indikator keempat, skor rendah juga diperoleh pada indikator keenam. Berdasarkan isian angket yang diisi oleh guru diketahui bahwa guru jarang membimbing peserta didik untuk mengembangkan diri melalui kegiatan ekstrakurikuler, kadang-kadang mengembangkan aspek sosial dalam pembelajaran, serta kadang-kadang dalam mengembangkan potensi keterampilan peserta didik dalam pembelajaran yang terdiri atas keterampilan belajar dan keterampilan berpikir.

\section{d. SMAN 1 Seyegan}

Berdasarkan hasil analisis angket dari guru tentang kemampuan guru mengimplementasikan Kurikulum 2013 ditinjau dari kompetensi pedagogik guru biologi, total skor yang diperoleh adalah 85 (69\%), sehingga masuk dalam kategori cukup mampu. Skor ini merupakan hasil isian angket yang diberikan kepada guru biologi yang terdiri atas 34 butir soal untuk menilai 10 indikator kompetensi pedagogik guru dalam mengimplementasikan Kurikulum 2013. 
Dari 10 indikator tentang kompetensi pedagogik guru, indikator keenam yaitu kemampuan guru dalam memfasilitasi pengembangan potensi peserta didik untuk mengaktualisasikan berbagai potensi yang dimiliki mendapatkan skor terendah yaitu 16 dari skor maksimal 30. Berdasarkan angket yang diisi guru, dapat diketahui bahwa guru jarang membimbing peserta didik untuk mengembangkan diri melalui kegiatan esktrakurikuler, serta hanya sekali dalam satu semester untuk membimbing kegiatan penyelidikan dan penelitian. Guru jarang memimbing peserta didik untuk mengembangkan diri melalui kegiatan ekstrakurikuler karena sekolah tidak menyediakan waktu di luar jam pelajaran untuk kegiatan praktikum. Kegiatan praktikum dilakukan pada jam pelajaran sekolah, sehingga untuk kegiatan ekstrakurikuler guru tidak melakukannya.

\section{e. SMAN 1 Godean}

Berdasarkan hasil analisis angket dari guru tentang kemampuan guru mengimplementasikan Kurikulum 2013 ditinjau dari kompetensi pedagogik guru biologi, total skor yang diperoleh adalah 103 (83\%), sehingga dapat dikategorikan sangat mampu). Skor ini merupakan hasil isian angket yang diberikan kepada guru biologi yang terdiri atas 34 butir soal untuk menilai 10 indikator kompetensi pedagogik guru dalam mengimplementasikan Kurikulum 2013.

Sama seperti guru SMAN 1 Prambanan, SMAN 2 Ngaglik, serta SMAN 1 Pakem, untuk guru SMAN 1 Godean juga diketahui dari 10 indikator tentang kompetensi pedagogik guru, indikator keempat yaitu kemampuan guru dalam menyelenggarakan pembelajaran yang mendidik mendapatkan skor terendah yaitu 15 dari skor maksimal 20 . Skor ini diperoleh berdasarkan angket yang diisi oleh guru. Pada inikator keempat, diketahui bahwa guru pernah 2 kali dalam menggunakan model pembelajaran Problem
Based Learning dan Inquiry dalam satu semester. Berdasarkan wawancara terhadap guru diketahui bahwa guru jarang menggunakan model pembelajaran ini karena materi yang diajarkan untuk kelas XI semester 2 kurang cocok apabila harus menggunakan model tersebut. Dalam hal ini, guru lebih banyak menggunakan model pembelajaran kooperatif dibandingkan model pembelajaran lainnya. Menurut guru, model pembelajaran ini lebih efektif dalam menyampaikan materi yang diajarkan. Hal ini dikarenakan peserta didik perlu bekerja sama dalam kelompok untuk mempresentasikan satu topik yang diberikan guru terkait dengan materi yang diajarkan.

\section{KESIMPULAN DAN SARAN}

a. Kesimpulan

Dari hasil analisis dan pembahasan dapat disimpulkan bahwa tingkat kemampuan guru biologi dalam mengimplementasikan Kurikulum 2013 ditinjau dari kompetensi pedagogik di SMA Negeri Kabupaten Sleman yaitu satu orang guru dengan kategori sangat mampu, tiga orang guru dengan kategori mampu, serta satu orang guru dengan kategori cukup mampu. Untuk kompetensi pedagogik, umumnya indikator penyelenggaraan pembelajaran yang mendidik serta penyelenggaraan penilaian dan evaluasi proses dan hasil belajar mendapatkan hasil yang kurang.

\section{b. Saran}

Berdasarkan simpulan, maka saran dalam penelitian ini adalah: (1) untuk guru yang tingkat kemampuannya rendah perlu mendapatkan pelatihan tentang implementasi Kurikulum 2013 dari pemerintah terutama pada proses pembelajaran, penilaian, evaluasi proses dan hasil belajar peserta didik; (2) guru perlu selalu meng-update informasi-informasi baru untuk meningkatkan kompetensi pedagogiknya.

\section{DAFTAR PUSTAKA}


Ghufron, A. (2008). Optimalisasi kegiatan inovatif guru dalam implementasi kurikulum di sekolah. Yogyakarta: UNY.

Mulyasa, E. (2005). Kurikulum berbasis kompetensi: konsep, karakteristik, dan implementasi. Bandung: Remaja Rosdakarya.

Mulyasa. (2010). Implementasi kurikulum tingkat satuan pendidikan. Jakarta: Bumi Aksara.

Mulyasa. (2014). Pengembangan dan implementasi kurikulum 2013. Bandung: Remaja Rosdakarya.

Setyarahajoe, R. \& Irtanto. (2013). The competence of teacher as human resouces at senior high school of kediri city east java province. SAVAP International, 4 (1), 40-49. 